\title{
MNEs' Subsidiary HRM Practices and Firm Innovative Performance: A Tacit Knowledge Approach
}

\author{
Rong Li ${ }^{1}$, Yi-Fei Du ${ }^{1}$, Hong-Juan Tang ${ }^{1, *}$, Francis Boadu ${ }^{1}$ (D) and Min Xue ${ }^{2}$ \\ 1 School of Management and Economics, University of Electronic Science and Technology of China, \\ Chengdu 611731, China; lizirong1001@foxmail.com (R.L.); duyf@uestc.edu.cn (Y.-F.D.); \\ linnacus@yahoo.com (F.B.) \\ 2 School of Management, China West Normal University, Nanchong 637009, China; \\ xuem120016@cwnu.edu.cn \\ * Correspondence: 201732110142@std.uestc.edu.cn
}

Received: 30 January 2019; Accepted: 1 March 2019; Published: 6 March 2019

\begin{abstract}
Although there is a general recognition that human resource management (HRM) practices are a key factor in a firm's innovation performance, from the extant literature we see that empirical investigation does not always offer evidence to support this assertion. This paper proposes that knowledge transfer received positively moderates the link between HRM practices and firm innovative performance in foreign multinational enterprises (MNEs) subsidiaries operating in China. Specifically, the influence of tacit knowledge approach on the effects of knowledge transfer received on HRM practices and firm innovative performance. With hierarchical linear modeling, our results demonstrate that: (1) HRM practices can have a positive effect on firm innovative performance; (2) knowledge transfer received can positively moderate the effects of HRM practices and firm innovative performance; and (3) the positive effects of knowledge transfer received on HRM practices and firm innovative performance will be strengthened with a tacit knowledge approach. This paper shows that through the adaptation and application of a tacit knowledge approach, executives can create an atmosphere for interaction between the workforce and senior colleagues, forming an inter-intra network chain to share intangible knowledge that is mostly derived from the culture and experience.
\end{abstract}

Keywords: HRM; knowledge transfer received; tacit knowledge approach; firm innovative performance

\section{Introduction}

Innovation is regarded as a key factor to firm survival and sustainability in this turbulent market environment. Thus, it is one of the principal conduits through which firms can attain sustainable expansion. It plays a momentous role in accomplishing competitive advantage, organizational performance [1,2], and economic growth. Scholars [3,4] have revealed the importance of innovation in the area of firms' growth, expansion, profitability, market value, and share. For the past few decades, many firms operating in emerging economies have been attempting to become innovators to compete squarely with their counterparts from developed market economies. Accomplishing these tasks requires the implementation of effective human resource management (HRM) practices and knowledge management strategies, which are crucial performance-enhancing antidotes to respond positively to today's ever-changing business landscape. HRM practices have been considered as a package or scheme that jointly supplements the skills and incentive of the workforce [5-7]. Admittedly, it can sharpen the attitude, skills, behavior, knowledge, and experience of workforce to think outside the box and develop creative ideas to facilitate a firm's innovative strategies [8]. We argue that HRM practices 
contribute to a firm's innovation strategies by inspiring the workforce in the area of knowledge creation to enhance the entire organizational knowledge base towards sustainable performance. According to Coff and Kryscynski [9], HRM practices aid firms' innovative strategies in order so that they can have a competitive advantage [10] in the market. However, from the extant literature, research reports on the connection among HRM practices and firm innovation performance are rare and have provided contradictory results [11-14]. Some authors [15-17] believe that HRM practices are indirectly related to the innovation performance of organizations. This paradoxical confrontation highlights the need for further studies to broaden the understanding of practitioners and scholars. It is also argued that knowledge transfer can play a significant role in HRM practices' influence on innovation. However, there is a paucity of research addressing the potential significance of knowledge as an antecedent of a firm's innovative performance $[18,19]$. Few studies that focused on this interplay have indicated that a positive relationship exists between these two variables [20-23]. However, the connections among the three dimensions have rarely been examined [24,25]. The present paper aims to fill this gap by constructing a moderated model that demonstrates the connection between HRM practices and firm innovative performance, while at the same time integrating knowledge transfer received and the tacit knowledge approach on foreign multinational enterprises (MNEs) subsidiaries operating in China. It is against this backdrop that this study attempts to address the following research questions: RQ1. Do HRM practices influence a firm's innovative performance directly? RQ2. Does knowledge transfer received play a facilitating role between HRM practices and a firm's innovative performance? RQ3. Which factor, explicit or tacit knowledge, has the greater influence on the effects of knowledge transfer received on HRM practices and a firm's innovative performance?

The contribution of this study is twofold. First, previous studies [11-17] pay attention to the two variables (i.e., the link between HRM practices and firm innovative performance), which has created a paradox in the literature. To address the paradoxical nature of the variables, we have extended the study by exploring the knowledge transfer mechanisms that boost innovative performance. We provide an enriched theoretical explanation of the role of knowledge transfer received in organizational settings. Our empirical results, based on the moderated moderation logical framework, demonstrate a significant positive interaction between HRM practices and knowledge transfer received, which supports the positive moderating effect proposed in the study. Boadu, et al. [26] emphasize that knowledge transfer is a key method of generating innovation towards a competitive advantage. They postulate that knowledge transfer received from the inter-intra network augments the existing stock of resources to enhance innovative performance. Thus, our findings improve the innovation literature, providing a new predictor of innovation capability. Second, we extend the notion of knowledge in resource-based view (RBV). As a key concept in the knowledge management literature, limitation of resources at times stifles firms' pursuit of innovative strategies $[27,28]$ for competitive advantage. Accordingly, such situations lead firms to seek a balance between tacit and explicit knowledge [29] as they cannot simultaneously focus on both of them to drive the organization innovative agenda. This definitely pressures firms to select tacit or explicit knowledge in facilitating innovation formation. Explicitly, firms that are eager to achieve competitive advantage concentrate on the dominance direction (tacit or explicit) for the implementation of key innovation strategies. In this study, we assume that the positive moderating effect of knowledge transfer received on the relationship between HRM practices and firm innovative performance will be strengthened when it is combined with a tacit knowledge approach. Our findings revealed that the tacit knowledge approach strengthens the moderation effects of knowledge transfer received on the relationship between HRM practices and firm innovative performance. Thus, the tacit knowledge approach is more suitable for firms to improve innovation performance. Nonaka, et al. [30] confirm that the appropriate maintenance of a firm's tacit knowledge can play an influential role in innovation performance, leading to a competitive advantage. This study therefore extends the empirical support for RBV.

The remainder of this paper is organized as follows. Section 2 delves into the theories related to the topic. Section 3 highlights hypothesis development. Section 4 contains the empirical analysis. 
Section 5 sheds more light on the empirical results. The last two sections present the conclusions, discussion, implications, limitations, and future research directions.

\section{Theories}

\subsection{Human Resource Management (HRM) Practices}

HRM actions in an organizational setup serve as a crucial resource for organizational development. More importantly, such resources are valuable, sporadic, and harder for industry players to successfully replicate and substitute for in the market environment. They serve as a strategic tool to give a firm the upper hand to enact strategic goals [31]. Proponents of the resource-based view (RBV) have argued that firm resources serve as a vital source of competitive advantage [32]. The relevance of HRM as a support of competitive advantage has been noted by practitioners and academics [33].

Generally speaking, HRM practices are firm-specific assets and the proper implementation of such strategically valuable assets in an organization can enhance employees' knowledge, skills, abilities, and commitment, leading to a competitive advantage that is hard for competitors to replicate [32,34-40]. We argue that HRM practices play a significant role in aiding employees to develop unique knowledge, skills, abilities, and other characteristics to think outside the box and develop creative ideas, which, in turn lead to sustainable competitive advantage [8,16,17,41].

From the existing literature, scholars [38,42-44] have highlighted the principal elements of HRM practices as performance appraisal, training and development, participation, compensation, etc. Each measurement of HRM practices is strictly connected and reciprocally coordinated. Studies conducted by Schmelter et al. [45] have provided evidence of the respective impact of each dimension in the organizational outcome.

In this study, we argue that firms can obtain enhanced innovative performance when they use a bundle of HRM practices to effect changes in the business environment. Scholars [46-49] have affirmed the collective effect of HRM practices in an organization. Admittedly, the effect of a combination of diverse HRM practices is larger than that of the individual practices, which ultimately leads to organizational innovation $[5,50]$.

\subsection{Knowledge Transfer}

From the extant literature, the term "knowledge" has not yet been defined consistently among scholars. However, its fundamental role in economic or business development cannot be over-emphasized. Proponents of the knowledge-based view (KBV) have acknowledged knowledge as an intangible resource that can serve as a foundation of competitive advantage [51,52]. Polanyi [53] distinguishes knowledge into two categories, namely tacit and explicit knowledge. Tacit knowledge can be described as a type of knowledge that is not easy to acquire through verbal spoken means [54]. In fact, this type of knowledge can only be acquired through practices or interaction due to its embeddedness in individuals, or may reside in a firm's scheme of operations. Conversely, explicit knowledge can be easily acquired through formal and organized means [55]. It is embedded in both individuals and organizations. Explicit knowledge offers an expected setting and management of work responsibilities.

In a competitive market environment, for MNEs and their subsidiaries to become more competitive, transfer of knowledge (i.e., tacit or explicit) is crucial for superior innovative performance. Knowledge transfer can be regarded as a process of transferring knowledge from one part of the organization to another through a transferring network, to improve firm performance. Scholars like Pak, et al. [56] and Wathne, et al. [57] have concluded that knowledge transfer is a significant, competitive tool for firm performance, survival, and prosperity.

In this paper, we focus on knowledge transfer received, defined as the request made by the subsidiary based on intelligent survey of the business environment for tacit and explicit knowledge from the MNEs headquarters to create a competitive advantage and meet the specific demands of 
customers. Knowledge transfer received could be dominated by tacit knowledge as opposed to explicit knowledge; these two dimensions are not sharply divided. One vital variance among the knowledge types is that tacit knowledge is more personal and context-related than explicit knowledge. Therefore, the tacit knowledge approach could be defined as a way whereby an organization concentrates on tacit strategies more than others to push its innovation agenda. Indeed, the flow of tacit knowledge from headquarters can inject fresh ideas and vivacity into a firm and its employees to enhance new product advancement [58]. From the extant literature, researchers have done little to establish the exact impact of knowledge transfer from headquarters to subsidiaries. It is therefore imperative to further explore what impact subsidiaries that received the knowledge transfer have had on HRM practices and innovative performance. The next section presents the discussions leading to the research hypotheses.

\section{Hypotheses}

This paper intends to test the link between HRM practices and firm innovative performance. Specifically, we propose and assess the facilitating role of knowledge transfer received and the tacit knowledge approach in the link between HRM practices and firm innovative performance (see Figure 1).

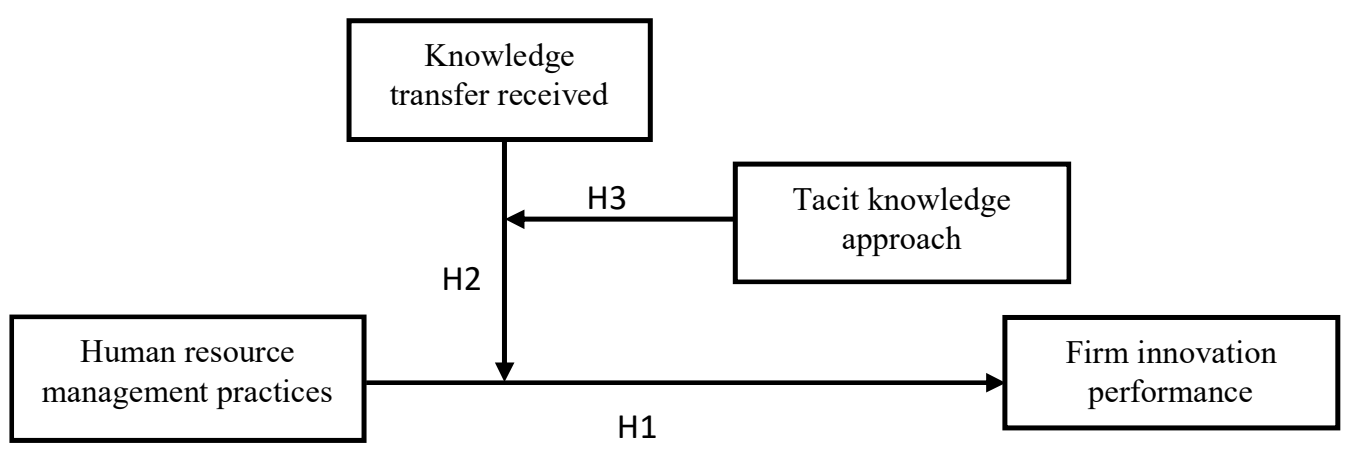

Figure 1. Logical framework.

\subsection{Human Resource Management Practices and Firm Innovative Performance}

HRM practices reflect a bundle of human resource management activities that strengthen the performance of an organization. They create an avenue for enhancing employees' skills, knowledge, ability, motivation, and opportunities in terms of work performance [59]. Firms aiming to record successful organizational outcomes can set HRM practices to work in tandem with all resources, especially human capital, to update employees' skills, knowledge, ability, motivation, and opportunity, leading to competitive advantage [5,60]. Various studies conducted on HRM practices and organizational performance have established a positive link [35,61-63]. On the innovation front, scholars [64-67] have found a strong interplay between HRM practices and innovation. However, some authors [15-17] believe that HRM practices are indirectly related to the innovation performance of organizations. This has created inconsistent results in the HRM and innovation literature. Therefore, the presence of inconclusive results suggests a need for further investigation in this area. In this study, we argue that subsidiaries can obtain enhanced innovative performance when they use bundle of HRM practices to effect changes in the business environment. We therefore hypothesize that:

Hypothesis 1 (H1). Human resource management practices have a positive effect on firm innovative performance.

\subsection{Knowledge Transfer Received as a Moderator of the Human Resource Management Practices and Firm Innovative Performance}

Because of firm-level differences that function as contingent forces, the effect of HRM practices on innovation performance has shown unequal results in the literature $[15-17,65]$. Contradictory 
views among scholars have been assigned various reasons, including the methodological approach, a combination of different industries, the distinct process of innovation, and the absence of a universal construct of HRM practices. To address this misgiving among HRM practices and innovation performance, we need to follow contingency logic [68] and moderate our variables by organizational factors such as the knowledge transfer variable. More importantly, for firms to have practices that are conducive to innovative performance, they need to critically look at their association with the nature of the environment and treat it as an optimal way to organize their activities as there is no best way to organize a firm [69]. Consequently, we postulate that the relative strength of HRM practices' influence on firm innovative performance depends on the knowledge transfer. Knowledge transfer can be classified as a unique resource that supports HRM practices directed at achieving innovative firm performance. Admittedly, scholars [70-72] have suggested that knowledge transfer from headquarters influences subsidiaries' performance. The implementation of HRM practices is an interplay between firms and the resource. HRM practices integrate both internal and external resources of firms and is closely related to the knowledge receiving, conversion, and application. Naif Marouf [73] opines that knowledge transfer offers opportunities for knowledge sharing and co-operation, which eventually leads to the creation of new methods and practices to enhances organizational performance.

In the context of subsidiaries, we argue that knowledge transfer received is important for subsidiaries to maximize innovation [74]. Proactive subsidiaries are likely to scan their operating environment to identify the social and environmental needs of the market and request knowledge from headquarters to combine with local knowledge. Therefore, the importance of knowledge transfer received cannot be over-emphasized in firms' innovation agenda as it leads firms to add value to create innovative products, services. and processes in a quick and accurate manner. From the discussion, knowledge transfer received can have much more of a role to play in an organization, as it can help employees to update their skills, knowledge, abilities, and willingness to conduct innovation-related tasks. We therefore hypothesize that:

Hypothesis 2 (H2). Knowledge transfer received positively moderates the effects of human resource management practices and firm innovative performance.

\subsection{Knowledge Transfer Received, Human Resource Management Practices, Firm Innovative Performance, and Tacit Knowledge Approach}

RBV theorists have identified a strong interplay between a firm's knowledge base and its competitive advantage [75,76]. In today's competitive environment, for firms to create and enjoy a sustainable competitive advantage, different sets of knowledge (i.e., transfer from both external and internal sources) play an important role in producing creative solutions to address market and environmental demands. Admittedly, the accumulated knowledge influences employees' knowledge level, skills, and abilities, which in turn contribute to improved firm strategic innovation, and thus enhanced competitive advantage.

We dissect knowledge transfer received to establish the positive knowledge approach (i.e., explicit or tacit knowledge) on the above interaction effect. The dominant knowledge approach refers to the type of knowledge that a firm depends on to execute its innovation strategies. Compared with tacit knowledge, explicit knowledge can be easily acquired through a formalized and organized system. Its transferability within or between firm(s) is easy. Explicit knowledge can improve employees' expediency; it also stimulates idea generation, whereby employees propose new ideas and utilize them to achieve innovative targets [77]. In contrast, tacit knowledge is non-verbal, instinctive, and implicit, which makes its formalization tough and limits its ease of transfer across organizational boundaries. It serves as a source of competitive advantage as it shields firms against boundary leakages of firm-specific know-how and assets [78]. Therefore, tapping into tacit knowledge within and outside of the organization is imperative for creating a competitive advantage, leading 
to the survival and growth of a firm. Laursen [79] asserts that workers' access to an array of tacit knowledge encourages them to pursue innovation, which results in a firm's competitive advantage. Admittedly, the flow of tacit knowledge from headquarters can inject fresh ideas and vivacity into the firm and its employees to enhance new product advancements [58]. Previous studies that focused on the interplay between tacit knowledge and innovation performance indicated that a positive relationship exists between the two variables [20-23]. More importantly, the tacit knowledge approach has a positive effect on innovation because it facilitates interactions among employees and senior colleagues from other outlets, which encourages the free flow of new ideas and perspectives to enhance innovation. Proper HRM practices always play a key role in such interactions as a pathway for creativity and innovation. From the extant studies, little empirical research has been conducted on the moderating influence of the tacit knowledge approach in the interplay between HRM practices and firm innovative performance. We therefore propose introducing a strong positive three-way interaction (i.e., HRM practices, knowledge transfer received, and tacit knowledge approach) into firm innovative performance. We state that:

Hypothesis $3 \mathbf{~ ( H 3 ) . ~ T h e ~ p o s i t i v e ~ e f f e c t s ~ o f ~ k n o w l e d g e ~ t r a n s f e r ~ r e c e i v e d ~ o n ~ h u m a n ~ r e s o u r c e ~ m a n a g e m e n t ~}$ practices and firm innovative performance will be strengthened by a tacit knowledge approach.

\section{Empirical Analysis}

\subsection{Research Context}

We tested our hypotheses on foreign MNE subsidiaries operating in China. China, as a leading contender in the emerging economies, is an ideal place to determine the connections among the three constructs (HRM practices, knowledge transfer received, and firm innovative performance) at the firm level. We selected China for this research for three reasons. First, the country is second after the United States of America in terms of foreign direct investment [80], which creates a relevant opportunity to assess knowledge-related production and innovation. Second, the country has attracted knowledge-based firms over the past few decades due to the relaxation of its foreign ownership policies. Finally, from the extant related literature, most of the focus has been on the developed economies, and yet the majority of the world's entrepreneurs live in emerging and developing economies [81].

\subsection{Survey Instrument Design}

We developed a well-tested survey instrument for the study. First, we consulted the extant literature to identify well-established and verified scales [82,83]. Second, all questions were translated from English to Chinese and back to check the accuracy [84]. After that a template of the instrument was reviewed iteratively by a five-member team of experts in the area of international business, entrepreneurship, and human resource management to validate the questions. We considered all their concerns in the survey instrument. Finally, we conducted a pilot study using 33 MBA students who had a global business background to authenticate the measures in terms of their precision and suitability in the context of MNE subsidiaries' operations. The feedback received from the participants helped us to determine the clarity of the instructions and variables. Thus, we refined the instruments to suit the current trends.

\subsection{Data and Sample}

In order to gather data for hypothesis testing, we engaged the top executives of foreign MNEs subsidiaries who are alumni of the MBA and executive MBA (EMBA) programs of the University of Electronic Science and Technology of China (UESTC). The center website keeps a repository (e.g., demographic data-name, company name, position among others) of corporate captains who have passed through the center since the 1990s for research purposes. To gather information from foreign 
MNEs subsidiaries executives to ascertain the interaction among the three dimensions in the study, we adopted the following approach. First, an invitation e-mail was forwarded to the executives named in the MBA (EMBA) education center of UESTC that asked about their willingness to participate in the survey. The reasons, benefits, and confidential nature of the survey were elaborated to them. The feedback from the executives was positive and allowed us to proceed to the next stage of the process. Second, utilizing random sampling techniques, the survey questionnaire was uploaded to a web page and we sent the website link to the potential respondents. Our sample target for the study was 385 top executives. Third, we forwarded a reminder e-mail to the potential respondents five weeks after our initial mailing of the website link to prompt them about the survey. In total, we received 242 responses from the executives. That figure represents a $62.86 \%$ participation rate, which is good for research of such nature. In the next step, we subjected the entire questionnaire to a thorough scrutiny for the identification of missing values. Thirteen questionnaires were discovered to possess missing values. These questionnaires were removed from the set to make it 229 questionnaires, representing a $59.48 \%$ participation rate. The survey was conducted in late August to early October 2018.

\subsection{Variables and Measures}

The questions for the survey were given a Likert-type scale. The executives were asked to rate the statements on a seven-point scale ranging from strongly agree to strongly disagree.

\subsubsection{Independent Variable}

Our independent variable is HRM practices. Scholars [38,42-44,85-87] have highlighted the significant of HRM practices like performance appraisal, training and development, participation, and compensation on firm innovative performance. They are of the view that these constructs of HRM practices are related to enhanced commitment, lower turnover, and increased performance. We argue that a firm's application of employee development and motivation policies can impact positively on innovative performance. In this study, we concentrate on the principal constructs of HRM practices (i.e., performance appraisal, training and development, participation, and compensation) related to innovation performance to assess their impact on MNEs' subsidiary innovative performance. Thus, we measure the HRM practices using the above four dimensions. Referring to the existing scales by Huselid [38]; Becker and Gerhart [85]; Guthrie [86]; Sumelius, Björkman, Ehrnrooth, Mäkelä and Smale [42]; Kadiresan, Selamat, Selladurai, SPR and Mohamed [43]; Gupta and Shaw [44]; Delery and Doty [87]; and Jimenez-Jimenez and Sanz-Valle [88], we developed one item on each dimension and generated four items in total. The items include "our company placed a high priority on training and development of employees to be more creative and innovative," "our company frequently discussed with employees their present and future performance issues," "our company gives employees the opportunity to suggest improvements in the way things are done," and "our company pay reflects differences in employee contributions."

\subsubsection{Dependent Variable}

In this study, our dependent variable is firm innovative performance. To solicit information in order to measure firm innovative performance, we used variables designed by Zhang and Li [82] and Chen, et al. [89]. The items include "our company's patent applications have risen," "our company's novel products/services have increased," "our company's speed of developing novel products has improved," "our company ratio of novel product sales to total sales has increased," and "our company's overall innovation of new products/services has improved."

\subsubsection{Moderating Variables}

We have two moderating variables, namely knowledge transfer received and the tacit knowledge approach. In this study, we added tacit knowledge transfer received and explicit knowledge transfer received to measure the variable knowledge transfer received. The research scale developed by 
Dhanaraj, Lyles, Steensma and Tihanyi [83] was consulted and two items each (tacit and explicit) adapted. We also added two items each in order to meet the needs of the actual situation. The items to measure explicit knowledge transfer received include "our parent company transmits information on new technology to us from headquarters," "our parent company transmits new product knowledge to us from headquarters," "our parent company transmits know-how linked to the market to us from headquarters," and "our parent company transmits management systems and practices to us from headquarters." Conversely, the items to measure tacit knowledge received are "our parent company shares information on knowledge about foreign cultures and taste with us," "our parent company shares information on market operation knowledge with us," "our parent company shares relationship-linked know-how and skills with us," and "our parent company share competitive behavior information with us."

Subsidiaries' tacit knowledge approach refers to a process whereby subsidiaries receive knowledge (e.g., experience and skills sharing) from headquarters mainly through a tacit approach. Few studies give an existing scale. With reference to Polanyi [53]'s definition [54], and Dhanaraj, Lyles, Steensma and Tihanyi [83]'s description of tacit and explicit knowledge [84], we measured the two approaches adopted by subsidiaries to receive knowledge from headquarters. The first approach concentrates on experience and skills sharing: we used the item "our parent company mainly transmits knowledge to us through employee interaction and experience sharing." The second approach concentrates on expression of words or numbers based on a codified or structured style: we used the item "our parent company mainly transmits knowledge through formal process documents or training materials." The scores for the two items were counted and the variable corresponding to the item with a higher score was regarded as the dominant approach of the subsidiary. We also used the dummy variable $(0,1)$ to make the measurement.

\subsubsection{Control Variables}

For us to have a more accurate picture of the effect of HRM practices on firm innovative performance, we engaged a number of important variables (firm size, firm age, industry characteristics, and research and development (R\&D) intensity) to guide our statistical results.

First, the size of a firm can potentially have an effect on innovation performance [26]. For instance, a large firm can bring on board economies of scales and synergies that have a direct effect on performance. However, at times, a large firm can also negatively affect development due to the dwindling marginal benefit of the scale. Therefore, we consider firm size as one of the control variables in the interaction between HRM practices and firm innovative performance. Ahuja [90] argues that firm size can be measured by the number of employees when it is a controlling variable of innovative performance. We control for firm size, measured by the natural logarithm of the number of employees. This study divides the firm size into five levels: 1 represents fewer than 200 people, 2 represents 200-499 people, 3 represents 500-999 people, 4 represents 1000-4999 people, and 5 represents more than 5000 people.

Second, the age of a firm can have an impact on innovation performance. Indeed, firm age demonstrates the life cycle effects. Prior studies have provided contradictory results as to the impact of firm age on innovative performance [91,92]. However, some researchers believe that long-established firms have more innovative output because they have time to accumulate knowledge [93]. Also, they have access to capital, which can help them to vary their business activities and have good performance. This study considers that firm age may have an impact on innovative performance. Therefore, we treat firm age as a control variable. According to the common practice of academia, we control for firm age by using the difference between the year of questionnaire recovery and the year of firm establishment as the age of the firm.

Third, the type of industry can affect the innovation performance of an organization. Generally speaking, because of the differences in resources, production methods, and demand, the innovation ability of firms in different categories of business may be dissimilar [26,94]. Heidenreich [95] discovers 
that when the technological content of the industry is low, the internal innovation ability of the firms become weak, and therefore a firm's innovation activities start to depend more on the acquisition of external resources. We control for industry type (i.e., manufacturing, service, and agriculture), measured by the following codes 1, 2, and 3. Specifically, 1 represents manufacturing, 2 represents service, and 3 represents agriculture.

Lastly, prior studies have regarded research and development (R\&D) intensity as a substantial factor in enhancing firm innovative performance towards competitive advantage and sustainability in the international market $[26,96,97]$. Firms' investment in knowledge generation and innovation through R\&D programs contributes significantly to innovation performance [26,98]. Consequently, we consider the intensity of R\&D investments as one of the control variables in the interaction between HRM practices and firm innovative performance. This variable is measured by the level of research and development expenditure relative to key competitors.

\subsection{Data Processing and Analysis}

First, we subjected all the data gathered into various tests (e.g., reliability, construct reliability, average variance extracted, validity, confirmatory factor analysis, etc.) with the help of statistics or data analysis (SPSS 23.0), to assess the measurement model. This scenario allows us to detail the relationships among the observable variables and theoretical concepts.

Second, to test the hypotheses, a data analysis technique (i.e., hierarchical linear modeling (HLM)) was utilized to determine whether HRM practices can influence firm innovative performance, which is moderated by knowledge transfer, and whether the positive effects of knowledge transfer on HRM practices and firm innovative performance will be strengthened with a tacit knowledge approach. This method (i.e., HLM) is appropriate, because the data for the study stem from incongruent organizational level [26,99].

\section{Results}

\subsection{Measurement Testing}

We adopted Cronbach's $\alpha$ coefficient and exploratory factor to examine the distinctiveness of three main variables (i.e., HRM practices, knowledge transfer received: explicit and tacit, and firm innovative performance). We also calculated the average variance extracted (AVE) and the composite reliability (CR) for all the constructs. Table 1 presents the results of reliability test, Kaiser-Meyer-Olkin (KMO), AVE, and CR of the variables from the dataset obtained from MNEs' subsidiaries. It shows that all the values from various tests are above the recommended levels. This demonstrates that the internal consistency, construct validity, and convergent validity are at a satisfactory level. In addition, we conducted discriminant validity tests with the aim of explaining the degree to which the constructs are different from each other.

Table 1. Construct reliability and validity.

\begin{tabular}{cccccc}
\hline Construct & Items & Cronbach's $\alpha$ & KMO & AVE & CR \\
\hline 1. HRM Practices & 4 & 0.749 & 0.755 & 0.572 & 0.842 \\
2. Explicit KTR & 4 & 0.696 & 0.737 & 0.524 & 0.815 \\
3. Tacit KTR & 4 & 0.694 & 0.712 & 0.525 & 0.814 \\
4. FIP & 5 & 0.861 & 0.856 & 0.643 & 0.900 \\
\hline
\end{tabular}

HRM Practices human resource management practice, Explicit KTR explicit knowledge transfer, Tacit KTR tacit knowledge transfer, FIP firm innovative performance.

Source: Authors' calculation.

\subsection{Descriptive Statistics and Correlations}

Table 2 shows the descriptive statistics including the means, standard deviations, square roots of $\mathrm{AVE}$, and intercorrelations of variables calculated from data obtained from MNEs subsidiaries. It also 
displays the result of square roots of AVE (diagonal element in parentheses) and their correlation with each construct of the study. As can be seen, the values of square roots of AVE are greater than 0.5 and also higher than respective correlation coefficient elements. This suggests that all dimensions in the measurement model meet the requirements for the study, and therefore the discriminant validity among the latent variables is strong.

Table 2. Descriptive statistics and correlation matrix for all study variables.

\begin{tabular}{|c|c|c|c|c|c|c|c|c|c|c|}
\hline Variable & 1 & 2 & 3 & 4 & 5 & 6 & 7 & 8 & 9 & 10 \\
\hline 1. FIP & $(0.802)$ & & & & & & & & & \\
\hline 2. HRM Practices & $0.314^{* *}$ & $(0.756)$ & & & & & & & & \\
\hline 3. Tacit KTR & -0.007 & 0.005 & $(0.725)$ & & & & & & & \\
\hline 4. Explicit KTR & $0.170 *$ & $0.214^{* *}$ & $0.205^{* *}$ & $(0.724)$ & & & & & & \\
\hline 5. TKD approach & $-0.213^{* *}$ & -0.036 & $0.163 *$ & -0.095 & - & & & & & \\
\hline 6. EKD approach & 0.037 & -0.054 & -0.122 & 0.032 & $-0.525^{* *}$ & - & & & & \\
\hline 7. Firm Size & $0.242^{* *}$ & 0.073 & 0.024 & 0.082 & -0.046 & 0.011 & - & & & \\
\hline 8. Firm Age & 0.005 & 0.089 & 0.113 & 0.072 & -0.030 & -0.016 & $0.293 * *$ & - & & \\
\hline 9. Service & -0.170 * & -0.081 & -0.005 & -0.062 & -0.007 & -0.063 & $0.305^{* *}$ & -0.117 & - & \\
\hline 10. R\&D Intensity & $0.310 * *$ & 0.088 & -0.076 & 0.036 & -0.097 & -0.021 & -0.042 & -0.012 & 0.074 & - \\
\hline Mean & 4.644 & 4.833 & 4.771 & 4.814 & 0.380 & 0.310 & 2.991 & 2.729 & 0.568 & 2.035 \\
\hline S.D. & 1.056 & 1.069 & 0.853 & 0.938 & 0.486 & 0.464 & 1.417 & 1.041 & 0.496 & 0.655 \\
\hline
\end{tabular}

Note: ${ }^{*} P$ value $<0.05$ and ${ }^{* *} P$ value $<0.01$; (two-tailed, $N=229$ ). Data in parentheses are square roots of average variance extracted (AVE). FIP firm innovative performance, HRM Practices human resource management practice, Tacit KTR tacit knowledge transfer, Explicit KTR explicit knowledge transfer, TKD approach tacit knowledge approach, EKD approach explicit knowledge approach, RED Intensity research and development intensity.

Source: Authors' calculation.

\subsection{Hypotheses Testing}

Table 3 demonstrates the regression analysis results of the main and interaction effects of the study. It takes into consideration all the control variables.

Table 3. Results of hierarchical linear modeling analysis.

\begin{tabular}{|c|c|c|c|c|c|}
\hline \multirow[t]{2}{*}{ Variables } & \multicolumn{5}{|c|}{ Dependent Variable: Firm Innovative Performance } \\
\hline & Model 1 & Model 2 & Model 3 & Model 4 & Model 5 \\
\hline Firm Size & $0.239(0.047)^{* * *}$ & $0.231(0.045)^{* * *}$ & $0.215(0.044)^{* * *}$ & $0.206(0.043)^{* * *}$ & $0.208(0.044) * *$ \\
\hline Firm Age & $-0.077(0.061)$ & $-0.097(0.058)$ & $-0.098(0.058)$ & $-0.109(0.117)$ & $-0.111(0.121)$ \\
\hline Service & $-0.129(0.128) *$ & $-0.110(0.123)$ & $-0.109(0.121)$ & $0.237(0.087)^{* * *}$ & $0.273(0.089) * * *$ \\
\hline R\&D Intensity & $0.329(0.093)^{* * *}$ & $0.301(0.089)^{* * *}$ & $0.280(0.089)^{* * *}$ & $-0.117(0.056) *$ & $-0.108(0.058)$ \\
\hline HRM Practices & & $0.269(0.059)^{* * *}$ & $0.254(0.058)^{* * *}$ & $0.235(0.056)^{* * *}$ & $0.243(0.059) * * *$ \\
\hline KTR & & & $0.037(0.059)$ & $0.07(0.075)$ & $0.023(0.076)$ \\
\hline TKD approach & & & & $-0.219(0.116)^{* * *}$ & \\
\hline EKD approach & & & & & $0.061(0.124)$ \\
\hline KTR $\times$ TKD approach & & & & $0.032(0.117)$ & $0.045(0.122)$ \\
\hline HRM Practices $\times$ KTR & & & $0.162(0.058)^{* *}$ & $0.026(0.074)$ & $0.269(0.08)^{* *}$ \\
\hline $\begin{array}{l}\text { HRM Practices } \times \\
\text { KTR } \times \text { TKD approach }\end{array}$ & & & & $0.242(0.117)^{* *}$ & \\
\hline $\begin{array}{l}\text { HRM Practices } \times \\
\text { KTR } \times \text { EKD approach }\end{array}$ & & & & & $-0.145(0.115)$ \\
\hline$R^{2}$ & 0.166 & 0.235 & 0.257 & 0.316 & 0.262 \\
\hline F & $12.368^{* * *}$ & $14.994^{* * *}$ & $12.288^{* * *}$ & $11.557^{* * *}$ & $9.089 * * *$ \\
\hline
\end{tabular}

Note: ${ }^{* * *} P<0.001,{ }^{* *} P<0.01,{ }^{*} P<0.05$, (Standard error), $N=229 ; K T R$ (knowledge transfer) $=$ Tacit KTR + Explicit KTR.

Source: Authors' calculation.

First, Hypothesis 1 predicts that HRM practices have a direct effect on firm innovative performance. As shown in Table 3, Model 2, HRM practices are significantly correlated with firm innovative performance $\left(\beta=0.269, p<0.001, R^{2}=0.235\right)$. This suggests that HRM practices are a fundamental organizational capability building avenue for firms. Thus, Hypothesis 1 is supported.

Second, Hypothesis 2 proposes a positive moderating effect of knowledge transfer received on the relationship between HRM practices and firm innovative performance. Model 3 in Table 3 shows a significant positive interaction between HRM practices and knowledge transfer received $(\beta=0.162$, 
$p<0.01, R^{2}=0.257$ ), which supports the positive moderating effect proposed in Hypothesis 2 . Hence, Hypothesis 2 is validated.

Third, Hypothesis 3 projects that the positive moderating effect of knowledge transfer received on the relationship between HRM practices and firm innovative performance will be strengthened with a tacit knowledge approach. Mode 4 presents a strong positive three-way interaction (i.e., multiplication of HRM practices, knowledge transfer received, and tacit knowledge approach). The results revealed that the tacit knowledge approach moderates the effect of knowledge transfer received on the relationship between HRM practices and firm innovative performance $\left(\beta=0.242, p<0.01, R^{2}=\right.$ 0.316). Thus, Hypothesis 3 is verified. We also examined the effect of the explicit knowledge approach. Comparing with the former, the latter result is not significant (Model 5, $p>0.05$ ).

To further illustrate the moderating mechanism of knowledge transfer and the tacit knowledge approach from data obtained from MNEs subsidiaries, we used process software to map the corresponding effects (Figure 2). The upper part of Figure 2 shows that the link between HRM practices and firm innovative performance is significantly positive. At the same time, when knowledge transfer received is high (e.g., 1 standard deviation above the mean), the simple slope corresponding to HRM practices and firm innovative performance becomes larger. Therefore, knowledge transfer received enhances the positive relationship between HRM practices and firm innovative performance. Conversely, the lower part of Figure 2 shows that under the same knowledge transfer received condition, when tacit knowledge is high (e.g., 1 standard deviation above the mean), the simple slope becomes larger. Thus, the above positive moderating effect is further enhanced. Thus, the assumptions in this paper have been tested.

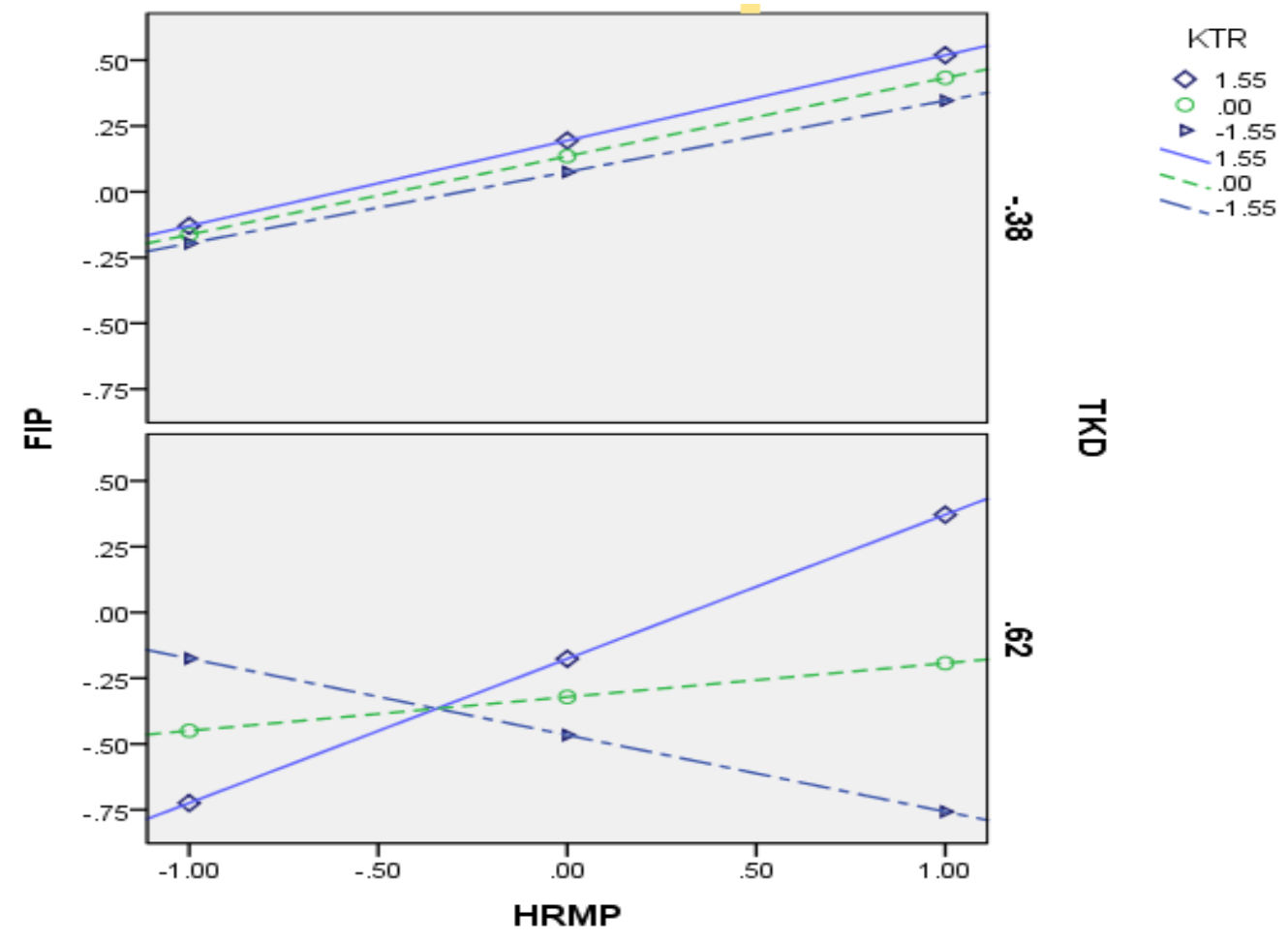

Figure 2. The moderating effects of knowledge transfer received and the tacit knowledge approach. Source: Authors' calculation.

\section{Discussion}

Management of human capital is regarded as a key to achieving organizational strategic goals. Scholars have described human capital as a strategic enabler, which influences a firm's creativity and innovation agenda $[100,101]$. Innovation is considered one of the fundamental sources of competitive 
advantage in the business circle. Proponents of RBV believe that for firms to have higher levels of competitive advantage, they need to develop innovation based on rare, valuable, and inimitable features. Our primary objective in this study was to better understand the circumstances under which HRM practices influence firm innovative performance in the MNEs' subsidiaries context, and the moderating role of knowledge transfer received. Specifically, we examined which factor (explicit or tacit) has the greater influence on the effect of knowledge transfer received on the relationship between HRM practices and firm innovative performance.

Our study makes a substantial contribution to the literature in several ways. First, the direct impact of HRM practices on innovation has created a dissimilarity in the HRM and innovation literature. Renowned researchers [11-14] assert that there is a direct link between HRM practices and innovation performance. However, other authors [15-17] have divergent views: they believe that there is an indirect link between the two variables. As can be seen from Table 3, our empirical results from the hierarchical linear modeling suggest that HRM practices are significantly correlated with firm innovative performance. This result confirms the effect of collective or collaborative HRM practices in organizational innovation activities [46-49]. Thus, our findings contribute to the debate on the impact of HRM practices on firm innovative performance and extend the prior studies in both innovation and HRM literature.

Second, we add to the arguments of authors [15-17] that say HRM practices are indirectly linked to the innovation performance of organizations. However, some scholars and practitioners have noted the important of HRM towards innovation. The extant studies in the literature provide scant examples of how to manage HRM practices to enhance innovation activities in organizations. Intriguingly, most researchers on innovation [102-104] focus on identifying the antecedents to innovation: the circumstances under which innovation arises, the procedures by which innovation proceeds, and its significance for organizational performance. The mechanism behind the impact of HRM practices on innovation has not been well recognized. In this paper, we delved into how knowledge transfer received from inter-intra network moderates the effect of HRM practices on firm innovative performance. The results based on the moderated moderation logical framework demonstrate a significantly positive interaction between HRM practices and knowledge transfer, which supports the positive moderating effect proposed in the study. Boadu, Xie, Du and Dwomo-Fokuo [26] emphasize that knowledge transfer is a key missile for generating innovation towards competitive advantage. They postulate that knowledge transfer from the inter-intra network network augments the existing stock of resources to enhance innovative performance. Our findings improve the innovation literature, providing a new predictor of innovation capability.

Third, we extend the notion of knowledge in RBV. As a key concept in the knowledge management literature, limitation of resources at times stifles firms' pursuit of innovative strategies $[27,28]$. Accordingly, such situations lead firms to make a compromise between tacit and explicit knowledge [29] as they cannot simultaneously focus on both. This definitely pressures firms into selecting tacit or explicit knowledge. Explicitly, firms that are eager to achieve a competitive advantage concentrate on the dominance direction (tacit or explicit) for implementation of key innovation strategies. In this study, we assume that the positive moderating effect of knowledge transfer received on the relationship between HRM practices and firm innovative performance will be strengthened when it is done with a tacit knowledge approach. Our findings revealed that the tacit knowledge approach strengthens the moderated effects of knowledge transfer received on the relationship between HRM practices and firm innovative performance. Thus, the tacit knowledge approach is more suitable to apply to a firm's innovation performance. Nonaka, Toyama and Konno [30] suggest that appropriate maintenance of a firm's tacit knowledge can play an influential role in innovation performance, leading to a competitive advantage. This study therefore extends the empirical support for RBV.

This paper has important implications for both practitioners and policy makers. First, our study has emphasized the importance of HRM practices in the process of innovation. We have argued that collective or collaborative HRM practices are crucial for a firm to increase its capacity to generate 
and absorb knowledge (internal and external) from diverse sources to facilitate innovation activities. Executives must create a conducive atmosphere and identify a collective bundle of HRM practices such as training and development, participation, compensation, and performance appraisal to stimulate creativity and innovation. These practices drive commitment, skills, abilities, and attitudes among employees to give their best to a firm's creativity and innovation agenda.

Second, knowledge transfer received from inter-intra network can form the foundation for creativity and innovation in organizations, which in turn can lead to superior innovative performance. Our study has established the role of knowledge transfer received on the interplay between HRM practices and firm innovative performance. Executives must manage knowledge (tacit and explicit) to create a competitive advantage. The combination of the three variables (HRM practices, knowledge transfer received, and firm innovative performance) can be adopted by executives to make a difference in their industry. Also, executives should incorporate an open innovation system in their knowledge searching. An open innovation system can serve as a conduit for knowledge searching to strengthen internal resources.

Third, with respect to the positive tacit knowledge approach, it moderates the moderating role of knowledge transfer received on the relationship between HRM practices and firm innovative performance, we propose that with an adaptation and application of the tacit knowledge approach, executives can create an atmosphere for interaction between the workforce and senior colleagues to form an inter-intra network chain to share intangible knowledge, mostly derived from culture and experience. These encounters can boost employees' creative thinking, which in turn may lead to superior innovation.

Fourth, policy makers should collaborate with MNEs' subsidiaries to create good industrial harmony. They should give incentives to industry players to pave the way for executives to pay increased attention to rules and regulations governing HRM and innovation. This will encourage firms to create more opportunities that encourage employees to apply their skills, knowledge, abilities, and creative ideas into innovation, thereby enhancing the innovation index of the country.

\section{Limitations and Future Research}

Despite the contributions of this study, it had a couple of limitations that researchers can tackle in their future endeavors. First, the study focuses only on foreign subsidiaries operating in China. Future investigation might address this issue, looking at the broader picture by including local subsidiaries. Second, the study adopted the questionnaire as an instrument for data gathering. In future investigations, it would be interesting to examine this phenomenon by applying panel data for further validation. Third, this empirical study is merely a cross-sectional one, which may not satisfactorily reflect the causal relationship among the variables. Future research should consider longitudinal research design to examine the relationships among variables.

Author Contributions: Conceptualization: R.L.; Y.-F.D.; H.-J.T.; F.B.; \& M.X.; Formal analysis: R.L.; H.-J.T.; \& M.X.; Funding acquisition: Y.-F.D.; Investigation: R.L.; \& F.B.; Supervision: Y.-F.D.; Writing一original draft: R.L.; H.-J.T.; F.B.; Writing一review \& editing: R.L.; Y.-F.D.; H.-J.T.; F.B.; \& M.X.

Funding: This research was funded by the National Natural Science Fund of China (Project No.71672021) and the Chinese Universities Scientific Fund (Project No. ZYGX2015SKT01).

Acknowledgments: This research would not have been possible without the support of the National Natural Science Fund of China (Project No.71672021) and the Chinese Universities Scientific Fund (Project No. ZYGX2015SKT01). In addition, we would like to extend our thanks to the executives who agreed to participate in the survey.

Conflicts of Interest: The authors declare no conflict of interest.

\section{References}

1. Gomes, G.; Wojahn, R.M. Organizational learning capability, innovation and performance: Study in small and medium-sized enterprises (SMES). RAUSP 2017, 52, 163-175. [CrossRef] 
2. Phong, L.B.; Hui, L.; Son, T.T. How Leadership and Trust in Leaders Foster Employees' Behavior Toward Knowledge Sharing. Soc. Behav. Pers.: Int. J. 2018, 46, 705-720. [CrossRef]

3. Acemoglu, D.; Akcigit, U.; Alp, H.; Bloom, N.; Kerr, W. Innovation, Reallocation, and Growth. Am. Econ. Rev. 2018, 108, 3450-3491. [CrossRef]

4. Lynch, R.; Jin, Z. Knowledge and innovation in emerging market multinationals: The expansion paradox. J. Bus. Res. 2016, 69, 1593-1597. [CrossRef]

5. Delery, J.E.; Roumpi, D. Strategic human resource management, human capital and competitive advantage: Is the field going in circles? Hum. Res. Manag. J. 2017, 27, 1-21. [CrossRef]

6. Lepak, D.P.; Liao, H.; Chung, Y.; Harden, E.E. A Conceptual Review of Human Resource Management Systems in Strategic Human Resource Management Research. In Research in Personnel and Human Resources Management; Emerald Group Publishing Limited: Bingley, UK, 2006; Volume 25, pp. 217-271.

7. Guest, D.E. Human resource management and employee well-being: Towards a new analytic framework. Hum. Res. Manag. J. 2017, 27, 22-38. [CrossRef]

8. Prajogo, D.I.; Oke, A. Human capital, service innovation advantage, and business performance: The moderating roles of dynamic and competitive environments. Int. J. Oper. Prod. Manag. 2016, 36, 974-994. [CrossRef]

9. Coff, R.; Kryscynski, D.; Barney, J.B.; Ketchen, D.J.; Wright, M. Invited Editorial: Drilling for Micro-Foundations of Human Capital-Based Competitive Advantages. J. Manag. 2011, 37, 1429-1443. [CrossRef]

10. Collins, C.J.; Clark, K.D. Strategic human resource practices, top management team social networks, and firm performance: The role of human resource practices in creating organizational competitive advantage. Acad. Manag. J. 2003, 46, 740-751.

11. Donate, M.J.; De Pablo, J.D.S.; De Pablo, J.D.S. The role of knowledge-oriented leadership in knowledge management practices and innovation. J. Bus. Res. 2015, 68, 360-370. [CrossRef]

12. Liu, D.; Gong, Y.; Zhou, J.; Huang, J.-C. Human Resource Systems, Employee Creativity, and Firm Innovation: The Moderating Role of Firm Ownership. Acad. Manag. J. 2017, 60, 1164-1188. [CrossRef]

13. De Winne, S.; Sels, L. Interrelationships between human capital, HRM and innovation in Belgian start-ups aiming at an innovation strategy. Int. J. Hum. Resour. Manag. 2010, 21, 1863-1883. [CrossRef]

14. Sparrow, P. Strategic HRM, Innovation and HR Delivery for Human Resource Management, Innovation and Performance. In Human Resource Management, Innovation and Performance; Palgrave Macmillan: London, UK, 2016; pp. 15-31.

15. Cabello-Medina, C.; Lopez-Cabrales, A.; Valle-Cabrera, R. Leveraging the innovative performance of human capital through HRM and social capital in Spanish firms. Int. J. Hum. Resour. Manag. 2011, 22, 807-828. [CrossRef]

16. Lopez-Cabrales, A.; Pérez-Luño, A.; Cabrera, R.V. Knowledge as a mediator between HRM practices and innovative activity. Hum. Resour. Manag.: Publ. Coop. Sch. Bus. Adm. Univ. Mich. Alliance Soc. Hum. Resour. Manag. 2009, 48, 485-503. [CrossRef]

17. Chen, C.-J.; Huang, J.-W. Strategic human resource practices and innovation performance-The mediating role of knowledge management capacity. J. Bus. Res. 2009, 62, 104-114. [CrossRef]

18. Kaše, R.; Paauwe, J.; Zupan, N. HR practices, interpersonal relations, and intrafirm knowledge transfer in knowledge-intensive firms: A social network perspective. Hum. Resour. Manag.: Publ. Coop. Sch. Bus. Adm. Univ. Mich. Alliance Soc. Hum. Resour. Manag. 2009, 48, 615-639.

19. Soltis, S.M.; Brass, D.J.; Lepak, D.P. Social Resource Management: Integrating Social Network Theory and Human Resource Management. Acad. Manag. Ann. 2018, 12, 537-573. [CrossRef]

20. Alwis, R.S.-D.; Hartmann, E.; Alwis, R.S. The use of tacit knowledge within innovative companies: Knowledge management in innovative enterprises. J. Knowl. Manag. 2008, 12, 133-147. [CrossRef]

21. Dyck, B.; Starke, F.A.; Mischke, G.A.; Mauws, M. Learning to Build a Car: An Empirical Investigation of Organizational Learning. J. Manag. Stud. 2005, 42, 387-416. [CrossRef]

22. Ritala, P.; Olander, H.; Michailova, S.; Husted, K. Knowledge sharing, knowledge leaking and relative innovation performance: An empirical study. Technovation 2015, 35, 22-31. [CrossRef]

23. Forés, B.; Camisón, C. Does incremental and radical innovation performance depend on different types of knowledge accumulation capabilities and organizational size? J. Bus. Res. 2016, 69, 831-848. [CrossRef] 
24. Chuang, C.; Liao, H. Strategic human resource management in service context: Taking care of business by taking care of employees and customers. Pers. Psychol. 2010, 63, 153-196. [CrossRef]

25. Clark, I.; Colling, T. The management of human resources in project management-led organizations. Pers. Rev. 2005, 34, 178-191. [CrossRef]

26. Boadu, F.; Xie, Y.; Du, Y.-F.; Dwomo-Fokuo, E. MNEs Subsidiary Training and Development and Firm Innovative Performance: The Moderating Effects of Tacit and Explicit Knowledge Received from Headquarters. Sustainability 2018, 10, 4208. [CrossRef]

27. Kogan, L.; Papanikolaou, D.; Seru, A.; Stoffman, N. Technological Innovation, Resource Allocation, and Growth. Q. J. Econ. 2017, 132, 665-712. [CrossRef]

28. Xie, Y.; Du, Y.-F.; Boadu, F.; Shi, X.-Y. Executives' Assessments of Evolutionary and Leapfrog Modes: An Ambidexterity Explanation Logic. Sustainability 2018, 10, 2893. [CrossRef]

29. Loebbecke, C.; Van Fenema, P.C.; Powell, P. Managing inter-organizational knowledge sharing. J. Strateg. Inf. Syst. 2016, 25, 4-14. [CrossRef]

30. Nonaka, I.; Toyama, R.; Konno, N. SECI, Ba and Leadership: A Unified Model of Dynamic Knowledge Creation. Long Range Plan. 2000, 33, 5-34. [CrossRef]

31. Wernerfelt, B. A resource-based view of the firm. Strateg. Manag. J. 1984, 5, 171-180. [CrossRef]

32. Barney, J. Firm Resources and Sustained Competitive Advantage. J. Manag. 1991, 17, 99-120. [CrossRef]

33. Porter, M.E. Competitive Advantage: Creating and Sustaining Superior Performance; The Free Press: New York, NY, USA, 1985.

34. Longoni, A.; Cagliano, R. Human resource and customer benefits through sustainable operations. Int. J. Oper. Prod. Manag. 2016, 36, 1719-1740. [CrossRef]

35. Kianto, A.; Sáenz, J.; Aramburu, N. Knowledge-based human resource management practices, intellectual capital and innovation. J. Bus. Res. 2017, 81, 11-20. [CrossRef]

36. Chowhan, J.; Pries, F.; Mann, S. Persistent innovation and the role of human resource management practices, work organization, and strategy. J. Manag. Organ. 2017, 23, 456-471. [CrossRef]

37. Lepak, D.P.; Snell, S.A. Examining the Human Resource Architecture: The Relationships Among Human Capital, Employment, and Human Resource Configurations. J. Manag. 2002, 28, 517-543. [CrossRef]

38. Huselid, M.A. The impact of human resource management practices on turnover, productivity, and corporate financial performance. Acad. Manag. J. 1995, 38, 635-672.

39. Liu, F.; Chow, I.H.-S.; Xiao, D.; Huang, M. Cross-level effects of HRM bundle on employee well-being and job performance. Chin. Manag. Stud. 2017, 11, 520-537. [CrossRef]

40. Guan, X.; Frenkel, S. How HR practice, work engagement and job crafting influence employee performance. Chin. Manag. Stud. 2018, 12, 591-607. [CrossRef]

41. Scarbrough, H. Knowledge management, HRM and the innovation process. Int. J. Manpow. 2003, 24, 501-516. [CrossRef]

42. Sumelius, J.; Björkman, I.; Ehrnrooth, M.; Mäkelä, K.; Smale, A. What Determines Employee Perceptions of HRM Process Features? The Case of Performance Appraisal in MNC Subsidiaries. Hum. Resour. Manag. 2014, 53, 569-592. [CrossRef]

43. Kadiresan, V.; Selamat, M.H.; Selladurai, S.; Spr, C.R.; Mohamed, R.K.M.H. Performance Appraisal and Training and Development of Human Resource Management Practices (HRM) on Organizational Commitment and Turnover Intention. Asian Soc. Sci. 2015, 11, 162. [CrossRef]

44. Gupta, N.; Shaw, J.D. Employee compensation: The neglected area of HRM research. Hum. Resour. Manag. Rev. 2014, 24, 1-4. [CrossRef]

45. Schmelter, R.; Börsch, C.; Mauer, R.; Brettel, M. Boosting corporate entrepreneurship through HRM practices: Evidence from German SMEs. Hum. Resour. Manag. 2010, 49, 715-741. [CrossRef]

46. Demortier, A.-L. The Human Capital Contribution to the Company Performance: The Case of the Knowledge-Intensive Firms in Luxembourg; UCL-Université Catholique de Louvain: Leuven, Belgium, 2014.

47. Minbaeva, D.B. Strategic HRM in building micro-foundations of organizational knowledge-based performance. Hum. Resour. Manag. Rev. 2013, 23, 378-390. [CrossRef]

48. Jiang, K.; Lepak, D.P.; Hu, J.; Baer, J.C. How Does Human Resource Management Influence Organizational Outcomes? A Meta-analytic Investigation of Mediating Mechanisms. Acad. Manag. J. 2012, 55, 1264-1294. [CrossRef] 
49. McKinlay, A.; Starkey, K. Strategy and human resource management. Int. J. Hum. Resour. Manag. 1992, 3, 435-450. [CrossRef]

50. Delery, J.; Gupta, N. Human resource management practices and organizational effectiveness: Internal fit matters. J. Organ. Eff.: People Perform. 2016, 3, 139-163. [CrossRef]

51. Ferlie, E.; Crilly, T.; Jashapara, A.; Trenholm, S.; Peckham, A.; Currie, G. Knowledge mobilization in healthcare organizations: A view from the resource-based view of the firm. Int. J. Health Policy Manag. 2015, 4, 127-130. [CrossRef] [PubMed]

52. Alguezaui, S.; Filieri, R. A knowledge-based view of the extending enterprise for enhancing a collaborative innovation advantage. Int. J. Agil. Syst. Manag. 2014, 7, 116. [CrossRef]

53. Polanyi, M. The Tacit Dimension; Doubleday: Garden City, NY, USA, 1966.

54. Garrick, J.; Chan, A.; Carayannis, E.; Bedford, D. Knowledge management and professional experience: The uneasy dynamics between tacit knowledge and performativity in organizations. J. Knowl. Manag. 2017, 21, 872-884. [CrossRef]

55. Maravilhas, S.; Martins, J. Strategic knowledge management in a digital environment: Tacit and explicit knowledge in Fab Labs. J. Bus. Res. 2019, 94, 353-359. [CrossRef]

56. Pak, Y.S.; Ra, W.; Park, Y.-R. Understanding IJV performance in a learning and conflict mediated context. Int. Bus. Rev. 2009, 18, 470-480. [CrossRef]

57. Wathne, K.; Roos, J.; Von Krogh, G. Towards a Theory of Knowledge Transfer in a Cooperative Context. Manag. Knowl.: Perspect. Coop. Compet. 1966, 1, 55-81.

58. Hislop, D.; Bosua, R.; Helms, R. Knowledge Management in Organizations: A Critical Introduction; Oxford University Press: Oxford, UK, 2018.

59. Boxall, P.; Macky, K. Research and theory on high-performance work systems: Progressing the high-involvement stream. Hum. Res. Manag. J. 2009, 19, 3-23. [CrossRef]

60. Armstrong, C.; Flood, P.C.; Guthrie, J.P.; Liu, W.; MacCurtain, S.; Mkamwa, T. The impact of diversity and equality management on firm performance: Beyond high performance work systems. Hum. Resour. Manag. 2010, 49, 977-998. [CrossRef]

61. Rothenberg, S.; Hull, C.E.; Tang, Z. The Impact of Human Resource Management on Corporate Social Performance Strengths and Concerns. Bus. Soc. 2017, 56, 391-418. [CrossRef]

62. Teclemichael Tessema, M.; Soeters, J.L. Challenges and prospects of HRM in developing countries: Testing the HRM-performance link in the Eritrean civil service. Int. J. Hum. Resour. Manag. 2006, 17, 86-105. [CrossRef]

63. Saridakis, G.; Lai, Y.; Cooper, C.L. Exploring the relationship between HRM and firm performance: A meta-analysis of longitudinal studies. Hum. Resour. Manag. Rev. 2017, 27, 87-96. [CrossRef]

64. Donate, M.J.; Peña, I.; Sanchez de Pablo, J.D. HRM practices for human and social capital development: Effects on innovation capabilities. Int. J. Hum. Resour. Manag. 2016, 27, 928-953. [CrossRef]

65. Diaz-Fernandez, M.; Bornay-Barrachina, M.; Lopez-Cabrales, A. HRM practices and innovation performance: A panel-data approach. Int. J. Manpow. 2017, 38, 354-372. [CrossRef]

66. Lee, H.W.; Pak, J.; Kim, S.; Li, L.-Z. Effects of Human Resource Management Systems on Employee Proactivity and Group Innovation. J. Manag. 2019, 45, 819-846. [CrossRef]

67. Kaabi, A.A.A.; Elanain, H.A.; Ajmal, M.M. HRM practices and innovation performance with the mediating effect of knowledge sharing: Empirical evidence from Emirati ICT companies. Int. J. Innov. Learn. 2018, 24, 41-61. [CrossRef]

68. Donaldson, L. The Contingency Theory of Organizations; SAGE Publications: London, UK, 2001.

69. Oke, A.; Walumbwa, F.O.; Myers, A. Innovation Strategy, Human Resource Policy, and Firms' Revenue Growth: The Roles of Environmental Uncertainty and Innovation Performance. Decis. Sci. 2012, 43, $273-302$. [CrossRef]

70. Chirico, F.; Sirmon, D.G.; Sciascia, S.; Mazzola, P. Resource orchestration in family firms: Investigating how entrepreneurial orientation, generational involvement, and participative strategy affect performance. Strateg. Entrep. J. 2011, 5, 307-326. [CrossRef]

71. Kandemir, D.; Hult, G.T.M. A conceptualization of an organizational learning culture in international joint ventures. Ind. Mark. Manag. 2005, 34, 430-439. [CrossRef]

72. Buckley, P.; Clegg, J.; Tan, H. Knowledge transfer to China: Policy lessons from foreign affiliates. Transnatl. Corp. 2004, 13, 31-72. 
73. Naif Marouf, L. Social networks and knowledge sharing in organizations: A case study. J. Knowl. Manag. 2007, 11, 110-125. [CrossRef]

74. Van Wijk, R.; Jansen, J.J.P.; Lyles, M.A. Inter- and Intra-Organizational Knowledge Transfer: A Meta-Analytic Review and Assessment of its Antecedents and Consequences. J. Manag. Stud. 2008, 45, 830-853. [CrossRef]

75. Ahmad, A.; Bosua, R.; Scheepers, R. Protecting organizational competitive advantage: A knowledge leakage perspective. Comput. Secur. 2014, 42, 27-39. [CrossRef]

76. Theriou, G.; Aggelidis, V.; Theriou, N. The Mediating Effect of the Knowledge Management Process to the Firm's Performance: A Resource-Based View. Int. J. Econ. Bus. Adm. 2014, 2, 87-114.

77. Lundvall, B.-A.; Nielsen, P. Knowledge management and innovation performance. Int. J. Manpow. 2007, 28, 207-223. [CrossRef]

78. Arnett, D.B.; Wittmann, C.M. Improving marketing success: The role of tacit knowledge exchange between sales and marketing. J. Bus. Res. 2014, 67, 324-331. [CrossRef]

79. Laursen, K. Keep searching and you'll find: What do we know about variety creation through firms' search activities for innovation? Ind. Corp. Chang. 2012, 21, 1181-1220. [CrossRef]

80. Teng, L.; Huang, D.; Pan, Y. The Performance of MNE Subsidiaries in China: Does It Matter to Be Close to the Political or Business Hub? J. Int. Manag. 2017, 23, 292-305. [CrossRef]

81. Barkema, H.G.; Chen, X.-P.; George, G.; Luo, Y.; Tsui, A.S. West Meets East: New Concepts and Theories. Acad. Manag. J. 2015, 58, 460-479. [CrossRef]

82. Zhang, Y.; Li, H. Innovation search of new ventures in a technology cluster: The role of ties with service intermediaries. Strat. Mgmt. J. 2010, 31, 88-109. [CrossRef]

83. Dhanaraj, C.; A Lyles, M.; Steensma, H.K.; Tihanyi, L. Managing tacit and explicit knowledge transfer in IJVs: The role of relational embeddedness and the impact on performance. J. Int. Bus. Stud. 2004, 35, 428-442. [CrossRef]

84. Brislin, R.W. Back-Translation for Cross-Cultural Research. J. Cross-Cult. Psychol. 1970, 1, 185-216. [CrossRef]

85. Becker, B.; Gerhart, B. The impact of human resource management on organizational performance: Progress and prospects. Acad. Manag. J. 1996, 39, 779-801.

86. Guthrie, J.P. High-involvement Work Practices, Turnover, and Productivity: Evidence from New Zealand. Acad. Manag. J. 2001, 44, 180-190.

87. Delery, J.E.; Doty, D.H. Modes of Theorizing in Strategic Human Resource Management: Tests of Universalistic, Contingency, and Configurations. Performance Predictions. Acad. Manag. J. 1996, 39, 802-835. [CrossRef]

88. Jiménez-Jiménez, D.; Sanz-Valle, R.; Jimenez-Jimenez, D.; Sanz-Valle, R. Innovation and human resource management fit: An empirical study. Int. J. Manpow. 2005, 26, 364-381. [CrossRef]

89. Chen, J.; Chen, Y.; Vanhaverbeke, W. The influence of scope, depth, and orientation of external technology sources on the innovative performance of Chinese firms. Technovation 2011, 31, 362-373. [CrossRef]

90. Ahuja, G. Collaboration Networks, Structural Holes, and Innovation: A Longitudinal Study. Adm. Sci. Q. 2000, 45, 425. [CrossRef]

91. Anderson, R.C.; Reeb, D.M. Founding-Family Ownership and Firm Performance: Evidence from the S\&P 500. J. Financ. 2003, 58, 1301-1328.

92. Han, K.C.; Suk, D.Y. The effect of ownership structure on firm performance: Additional evidence. Rev. Financ. Econ. 1998, 7, 143-155. [CrossRef]

93. Sorensen, J.B.; Stuart, T.E. Aging, Obsolescence, and Organizational Innovation. Adm. Sci. Q. 2000, 45, 81. [CrossRef]

94. Köhler, C.; Sofka, W.; Grimpe, C. Selective search, sectoral patterns, and the impact on product innovation performance. Res. Policy 2012, 41, 1344-1356. [CrossRef]

95. Heidenreich, M. Innovation patterns and location of European low- and medium-technology industries. Res. Policy 2009, 38, 483-494. [CrossRef]

96. Cohen, W.M.; Levinthal, D.A. Absorptive Capacity: A New Perspective on Learning and Innovation. Adm. Sci. Q. 1990, 35, 128-152. [CrossRef]

97. Salim, R.A.; Bloch, H. Business expenditures on R\&D and trade performances in Australia: Is there a link? Appl. Econ. 2009, 41, 351-361.

98. Katila, R.; Ahuja, G. Something Old, Something New: A Longitudinal Study of Search Behavior and New Product Introduction. Acad. Manag. J. 2002, 45, 1183-1194. 
99. Bryk, A.S.; Raudenbush, S.W. Hierarchical Linear Models: Applications and Data Analysis Methods; Sage Publications: London, UK, 2002.

100. Lepak, D.P.; Snell, S.A. The Human Resource Architecture: Toward a Theory of Human Capital Allocation and Development. Acad. Manag. Rev. 1999, 24, 31-48. [CrossRef]

101. Subramaniam, M.; Youndt, M.A. The Influence of Intellectual Capital on the Types of Innovative Capabilities. Acad. Manag. J. 2005, 48, 450-463. [CrossRef]

102. McGrath, R.G.; Tsai, M.-H.; Venkataraman, S.; Macmillan, I.C. Innovation, Competitive Advantage and Rent: A Model and Test. Manag. Sci. 1996, 42, 389-403. [CrossRef]

103. Ramadani, V.; Abazi-Alili, H.; Dana, L.-P.; Rexhepi, G.; Ibraimi, S. The impact of knowledge spillovers and innovation on firm-performance: Findings from the Balkans countries. Int. Entrep. Manag. J. 2017, 13, 299-325. [CrossRef]

104. Zaefarian, G.; Forkmann, S.; Mitrega, M.; Henneberg, S.C. A Capability Perspective on Relationship Ending and Its Impact on Product Innovation Success and Firm Performance. Long Range Plan. 2017, 50, 184-199. [CrossRef]

(C) 2019 by the authors. Licensee MDPI, Basel, Switzerland. This article is an open access article distributed under the terms and conditions of the Creative Commons Attribution (CC BY) license (http:/ / creativecommons.org/licenses/by/4.0/). 